\title{
Synthesis of peptide derivatives of aspirin and their antibiogram
}

\author{
J. BALAMANI ${ }^{1 *}$, M. THANGAVEL $^{2}$ and M. SEKAR ${ }^{3}$ \\ ${ }^{1}$ Post Graduate and Research Department of Chemistry, Kongunadu Arts and \\ Science College, Coimbatore-641 029, India. \\ ${ }^{2}$ Post graduate and Research Department of Microbiology, Sree Narayana guru College, Coimbatore- 105. \\ ${ }^{3}$ Post graduate and Research Department, Sri Ramakrishna Mission Vidhyalaya college, Coimbatore. \\ *Corresponding author, E-mail: balamani_gokul@yahoo.co.in
}

\begin{abstract}
Peptide derivatives of Aspirin (1 to 8) were synthesized by using $\mathrm{Ac}_{2} \mathrm{O} / \mathrm{AcOH}$ reaction with Salicyclic acid. Aspirin was coupled with amino acid amide and dipeptide amide and tripeptide amide using its p-nitro phenyl $\left(\mathrm{N}_{\mathrm{P}}\right)$ ester. The ester (Aspirin- $\mathrm{ON}_{\mathrm{P}}$ ) was prepared using p-nitro phenol and DCC in EtOAc and was precipitated using EtOH. The synthesis of dipeptide amides were carried out in solution by stepwise elongation of the peptide chain from the C-terminal amino acid by coupling one amino acid at a time using DCC/HOBt method. Boc-group was used for $\mathrm{N}^{\alpha}$ protection of all amino acids. The Boc-group cleavage was carried out using $50 \% \mathrm{TFA} / \mathrm{CH}_{2} \mathrm{Cl}_{2}$. The amidation of $\mathrm{C}$-terminal amino acid was carried out by treating the corresponding Boc-amino acid-ONp esters with dry $\mathrm{NH}_{3}$ in presence of DCC and HOBt. These compounds were subjected to antibiotic susceptibility studies against the Pseudomonas fluorescens, Escherichia coli and Staphylococcus aureus. Methionine amide of aspirin was active on S. aureus. Glycyl-glycyl-phenylalanyl-leucine amide of aspirin was moderately active on all the three bacterial strains used. Glycyl-Phenylalanyl-leucine amide of aspirin and glycyl-glycyl-methionine amide of aspirin were active on $P$. fluorescens. Leucine amides of aspirin was moderately active on $S$. aureus Methionine amides of aspirin was highly active on E. coli. Phenylalanylleucine amides of aspirin and glycyl-glycyl-phenylalanyl-methionine amide of aspirin were active on none of the organisms used in this study. In general the peptide derivatives of aspirin $(1,3,4,5,6,7)$ were not active on all the three microbes used. Compounds 2 and 8 were sensitive to none of the organisms used in this study. By the major study, we observed that the derivative of aspirin showed a greater influence in inhibiting the test organisms used.
\end{abstract}

(C) 2009 International Formulae Group. All rights reserved.

Keywords: Aspirin-ONp, Boc- $\mathrm{N}_{3}$ (t-butyl azido formate), HOBt (1-Hydroxy benzotriazole), DCC (N, $\mathrm{N}^{1}-$ Dicyclo hexyl carbodiimide) and DCU (N, $\mathrm{N}^{1}$-Dicyclohexyl urea).

\section{INTRODUCTION}

Salicylic acid was found to possess analgesic activity (Patric, 2000) and it was used for the treatment of integumental pain, headache and reduces fever. Nevertheless, it was not used medicinally due to its side-effect of producing gastric disturbances. But their derivatives are found to be useful. Aspirin is used for musculo-skeletal disorders. In a sufficiently larger dose, aspirin acts as an antirheumatic and anti-platelet agent. In a single dose, aspirin produces only analgesic action. Use of analgesics requires an understanding of the biochemical and physiological mechanism of analgesics (Williams et al., 1981). To improve the solubility and to reduce the side effects of aspirin (Wilson et al., 1968) various salts like calcium salicylate, aluminium salicylate were introduced by blocking the free carboxyl group. Sodium and potassium salts of aspirin are unstable in contact with moisture. Fujii et al. (1982) were successful in 
the synthesis of peptides by coupling a large number of small segments (total of 30) ranging from di to octa peptides one by one starting from the carboxyl terminus. The incomplete cleavage of protecting groups leads to loss of biological activity (Kenner et al., 1979).

The most commonly used protecting group combination of $\mathrm{Z}$ and Boc are cleaved by catalytic hydrogenolysis. Beluzzi et al. (1975) and Birscher et al. (1976) were first to report the analgesic effect of Met-and Leuenkephalins through injection into lateral ventricles of rats, using the tail flick procedure. The peptides are found not only in the pituitary but also in neurons in the CNS where they probably serve as neurotransmitters with a wide spectrum of biological activity (Snyder, 1980). Infectious diseases are world's leading cause of premature death, killing almost 50,000 people every day (Anonymous, 2000). Resistance to antimicrobial agents is emerging in a wide variety of pathogens and multiple drug resistance is becoming common in diverse organisms such as S. aureus, S. sepidemidis, S. typhi, and S. paratyphi A (Threlfall et al., 1996; Gowan, 1999; Ahamed et al., 2001), this has necessitated a search for new antimicrobial substances from other sources including plants. Over the past 20 years, there has been a lot of investigation on plants as sources of new antimicrobial agents. But still there is an immediate need to identify novel substances active towards pathogens with high resistance (Reciomc, 1978; 1988; Cragg et al., 1997; Samy et al., 2000). Recent studies have shown that several alcoholic extracts of various traditional medicinal plants exhibit antibacterial activity (Ahamed et al., 2001; Akinyemiko et al., 2005). Anti Staphylococcal and anti - Salmonella activities of plants have also been reported (Perez et al., 1990; Polombo et al., 2002; Rani et al., 2004). P. aeruginosa is a leading cause of hospital acquired infections giving to a wide range of opportunistic infections. Its high intrinsic resistance to antibiotics and ability to develop multidrug resistance pose serious therapeutic problems (Livermore, 2002).

The term resistance implies that the organism is expected not to respond to a given drug irrespective of the dosage and of the location of the infection (Gales et al., 2001). The in vitro susceptibility patterns of the isolated bacteria to different antimicrobial agents were determined by disc diffusion technique (Cruckshank et al., 1975). Enterotoxigenic Escherichia coli (ETEC) strains are the major cause of diarrhoea in man and domestic animals. It has been estimated that only ETEC gives rise to 650 million cases of diarrhoea and 800,000 deaths annually in children under five years of age in developing countries (Black, 1986). Similarly, the impact of ETEC diarrhoea on young animals health is also of very high magnitude (Gyles, 1986). ETEC strains harbour several virulence factors, the important ones are plasmid encoded (heat labile, LT and or heat stable ST) enterotoxin(s) and plasmid or chromosome encoded adhesions which enable them to attach to and proliferate in small bowl (Blanco et al., 1991; Bertin, 1992; Gyles, 1992).

\section{MATERIALS AND METHODS}

Synthesis of peptide amides of aspirin

Boc-aminoacid $\mathrm{NH}_{2}$ was prepared using Boc-aminoacid /dry $\mathrm{NH}_{3} / \mathrm{DCC} / \mathrm{HOBt}$ and was obtained in about $85 \%$ yield. The synthesis of dipeptide amides, tripeptide amides, and tetrapeptide amides were carried out in solution by stepwise elongation of the peptide chain from the C-terminal amino acid by coupling one amino acid at a time using DCC/HOBt method (Kundu et al., 1986). Boc group (Carpino, 1957; Seigmund et al., 1957) was used for $\mathrm{N}^{\propto}$ protection of all amino acids. The Boc-group cleavage was carried out using $50 \% \mathrm{TFA} / \mathrm{CH}_{2} \mathrm{Cl}_{2}$. The amidation of $\mathrm{C}$ terminal amino acid was carried out by treating the corresponding Boc-aminoacid$\mathrm{ONp}$ esters with dry $\mathrm{NH}_{3}$ in presence of DCC and HOBt.

\section{Antibiogram study}

Swabs were prepared with absorbent cotton wool application stick. These swabs were then kept in suitable test tubes plugged with cotton wool and sterilized.

\section{Collection of samples}

The strains collected from the hospital environment were kept in transporting media and transported to the laboratory within 24 
hours. Until further processing, it was preserved in refrigerator.

\section{Identification of the organisms}

The organism authenticity was found by performing biochemical reactions and sugar fermentation tests. The results of biochemical reactions and sugar fermentation tests are tabulated in table I.

The following peptide derivatives were subjected to antibiotic susceptibility studies against the bacteria E. coli, P. fluorescens, $S$. aureus. using aspirin as the control.

$$
\begin{array}{ll}
\text { 1. } & \text { Asp - Leu - } \mathrm{NH}_{2} \\
\text { 2. } & \text { Asp -Phe - Leu - } \mathrm{NH}_{2} \\
\text { 3. } & \text { Asp - Gly -Phe - Leu - } \mathrm{NH}_{2} \\
\text { 4. } & \text { Asp - Gly- Gly- Phe- Leu - } \mathrm{NH}_{2} \\
\text { 5. } & \text { Asp - Met - NH} \\
\text { 6. } & \text { Asp - Gly- Met - } \mathrm{NH}_{2} \\
\text { 7. } & \text { Asp - Gly- Gly- Met - } \mathrm{NH}_{2} \\
\text { 8. } & \text { Asp - Gly- Gly- Phe- Met }-\mathrm{NH}_{2}
\end{array}
$$

In Paper disc method, organisms were cultivated in nutrient broth for testing the antibacterial activity against the synthesized peptide derivatives. Muller-Hinton agar plates were prepared and the organisms were inoculated onto it following streak plate method (Pal et al., 1999).

Peptide derivatives ( 1 to 8 ) and aspirin (control) were dissolved in DMSO in equal proportions. Whatmann's No 1 filter paper was cut into disc shape using a punching machine and was dipped into this mixture. Then the discs were taken out from the mixture using sterile forceps. These discs were placed on the Muller-Hinton agar plates that were streaked with the test organisms. The plates were then incubated at $37{ }^{\circ} \mathrm{C}$ for 24 hours. After the incubation, the plates were observed for the presence of any zone of inhibition, and the diameters of the zones were measured using a scale keeping aspirin as the control.

\section{RESULTS}

The compounds synthesized were confirmed by the IR, NMR spectrum and elemental analysis studies and the data are given below:

Data pertaining to a few selected compounds are as follows:

1. M.P. $109-111^{\circ} \mathrm{C}$; IR (KBr); $3394 \mathrm{~cm}^{-1}$ (asymmetric NH), $3207 \mathrm{~cm}^{-1}$ (sym. NH), 3351 $\mathrm{cm}^{-1} \quad(-\mathrm{CONH}),, \quad 1717 \quad \mathrm{~cm}^{-1}, \quad(>\mathrm{C}=\mathrm{O})$, ${ }^{1} \mathrm{HNMR} ; \quad(400 \mathrm{MHz})$ (DMSO); $\delta 2.5 \quad$ ($\left.\mathrm{COCH}_{3}\right), \delta 8(\mathrm{~N}-\mathrm{H})$ and $\delta 7.95\left(-\mathrm{NH}_{2}\right)$.

2. M.P. $138-140{ }^{\circ} \mathrm{C}$; IR $(\mathrm{KBr}) ; 3390 \mathrm{~cm}^{-1}$ (Asymm.NH); $\quad 3188 \mathrm{~cm}^{-1} \quad$ (symm.NH)., $3342 \mathrm{~cm}^{-1}$ (CONH), $1678 \mathrm{~cm}^{-1} \quad(>\mathrm{C}=\mathrm{O}),{ }^{1} \mathrm{H}$ NMR: $\delta 2.27\left(-\mathrm{COCH}_{3}\right), \delta 8.2$ (-NH-) $\delta 8.4$

$\left(-\mathrm{NH}_{2}\right)$.

\section{Elemental analysis}

Compound 1 Glycyl - Glycyl phenylalanyl - Methionine amide of Aspirin. $\mathrm{C}_{27} \mathrm{H}_{33} \mathrm{O}_{7} \mathrm{~N}_{5} \mathrm{~S}$ (571) is found to have $\mathrm{C}$ $56.74 \%, \mathrm{H}=5.78 \%$ and $\mathrm{N} 12.26 \%$.

Compound 2, Glycyl - Glycyl - Phenyl alanyl - leucine amide of Aspirin, $\mathrm{C}_{28} \mathrm{H}_{35} \mathrm{O}_{7}$ $\mathrm{N} 5(553)$ is found to have $\mathrm{C} 60.76 \%, \mathrm{H} 6.33 \%$ and $\mathrm{N} 12.66 \%$.

${ }^{1} \mathrm{H}$ NMR study

${ }^{1} \mathrm{H}$ NMR parameters of the amino acid residues (1) and (2) are Asp - Gly (1) - Gly (2) - Phe (3) - X (4) $-\mathrm{NH}_{2}$ (Table 2).

\section{Antibiogram}

Upon studying the sensitivity pattern of $E$. coli, P. fluorescens, S. aureus. against the various amides of aminoacids, dipeptides, tripeptides, and tetrapeptides, the following results were obtained and tabulated in the table 3.

Aspirin was used as a positive control that showed zone size of $15 \mathrm{~mm}$.

$P$. fluorescens showed a high sensitive activity against the aspirin methionine amide

Table 1: Results of Biochemical reactions and Sugar fermentation tests.

\begin{tabular}{llcccccccc}
\hline S.No & Organism & Indole & M.R. & V.P. & Citrate & Oxidase & Coagulase & Glucose & Lactose \\
\hline 1 & E.Coli & + & + & & - & - & - & A/G & A/G \\
2 & P.fluorecens & - & - & - & + & + & - & A & - \\
3 & S.aureus & - & + & + & - & - & + & A & A \\
\hline
\end{tabular}


Table 2: Proton NMR study.

\begin{tabular}{|c|c|c|c|}
\hline & Parameters & X(4) Leu & X(4) Met \\
\hline Gly (1) & $\begin{array}{c}\delta \mathrm{NH} \\
\delta \mathrm{CH}_{2}\end{array}$ & $\begin{array}{c}8.21 \\
3.2\end{array}$ & $\begin{array}{l}8.2 \\
3.4\end{array}$ \\
\hline Gly (2) & $\begin{array}{c}\delta \mathrm{NH} \\
\delta \mathrm{CH}_{2}\end{array}$ & $\begin{array}{c}8 \\
3.06\end{array}$ & $\begin{array}{l}7.8 \\
3.1\end{array}$ \\
\hline Phe (3) & $\begin{array}{c}\delta \mathrm{NH} \\
\delta \mathrm{C}^{\alpha} \mathrm{H} \\
\delta \mathrm{CH}_{2} \\
\delta \mathrm{C}_{6} \mathrm{H}_{5}\end{array}$ & $\begin{array}{c}8 \\
4.5 \\
3.6 \\
7.3\end{array}$ & $\begin{array}{c}8 \\
5.3 \\
3.4 \\
7.25\end{array}$ \\
\hline $\begin{array}{l}-\mathrm{NH}_{2} \\
-\mathrm{COCH}_{3}\end{array}$ & $\delta$ & $\begin{array}{c}7.95 \\
2.5\end{array}$ & $\begin{array}{c}8.4 \\
2.27\end{array}$ \\
\hline
\end{tabular}

The methyl resonance of methionine at $2.04 \mathrm{ppm}$, the isopropyl resonance of leucine at $4.5 \mathrm{ppm}$ (Bundi et al., 1975).

Table 3: Results of sensitivity pattern of Microorganisms.

\begin{tabular}{lccc}
\hline Compounds & E-Coli & P.fluorescens & S.aureus \\
\hline Aspirin & 15 & 15 & 15 \\
Asp - Leu - $\mathrm{NH}_{2}$ & - & - & 15 \\
Asp -Phe - Leu - $\mathrm{NH}_{2}$ & - & - & - \\
Asp - Gly -Phe - Leu - $\mathrm{NH}_{2}$ & 15 & - & 18 \\
Asp -Gly- Gly- Phe- Leu - $\mathrm{NH}_{2}$ & 15 & 14 & 18 \\
Asp - Met - NH & 22 & 17 & - \\
Asp - Gly- Met - NH & - & - & 17 \\
Asp - Gly- Gly- Met - $\mathrm{NH}_{2}$ & 17 & - & 18 \\
Asp -Gly- Gly- Phe- Met - $\mathrm{NH}_{2}$ & - & - & - \\
\hline
\end{tabular}

with $17 \mathrm{~mm}$ and the glycyl-glycylphenylalanyl-leucine amides of aspirin showed $14 \mathrm{~mm}$ and found to be moderately active whereas the remaining amides were not active. This is shown in plate 1 and figure 1.

$S$. aureus was highly sensitive to glycyl-phenylalanyl-leucine amides of aspirin, glycyl-glycyl-phenylalanyl-leucine amides of aspirin and glycyl-glycyl-methionine amides of aspirin giving $18 \mathrm{~mm}$ of inhibition zone size and leucine amide of aspirin showed 15 $\mathrm{mm}$, glycyl-methionine amides of aspirin showed $17 \mathrm{~mm}$ of inhibition of zone whereas the rest of the amides used phenylalanylleucine amides of aspirin, glycyl-glycylphenylalanyl-methionine amides of aspirin were not active. This is shown in plate 2 and figure 2

E. coli gave a very high sensitivity against methionine amides of aspirin with 22 $\mathrm{mm}$, glycyl-glycyl-methionine amides of aspirin giving $17 \mathrm{~mm}$, but glycyl-glycylphenylalanyl-leucine amides of aspirin and glycyl-phenylalanyl-leucine amides of aspirin inferred to be moderately active with $15 \mathrm{~mm}$. This is shown in plate 3 and figure 3 .

\section{DISCUSSION}

Aspirin has been shown by many authors to possess antimicrobial properties (Wang et al., 2003; Al-Bakri et al., 2009). It was used as the positive control in this study, and its activity was compared to those of its 


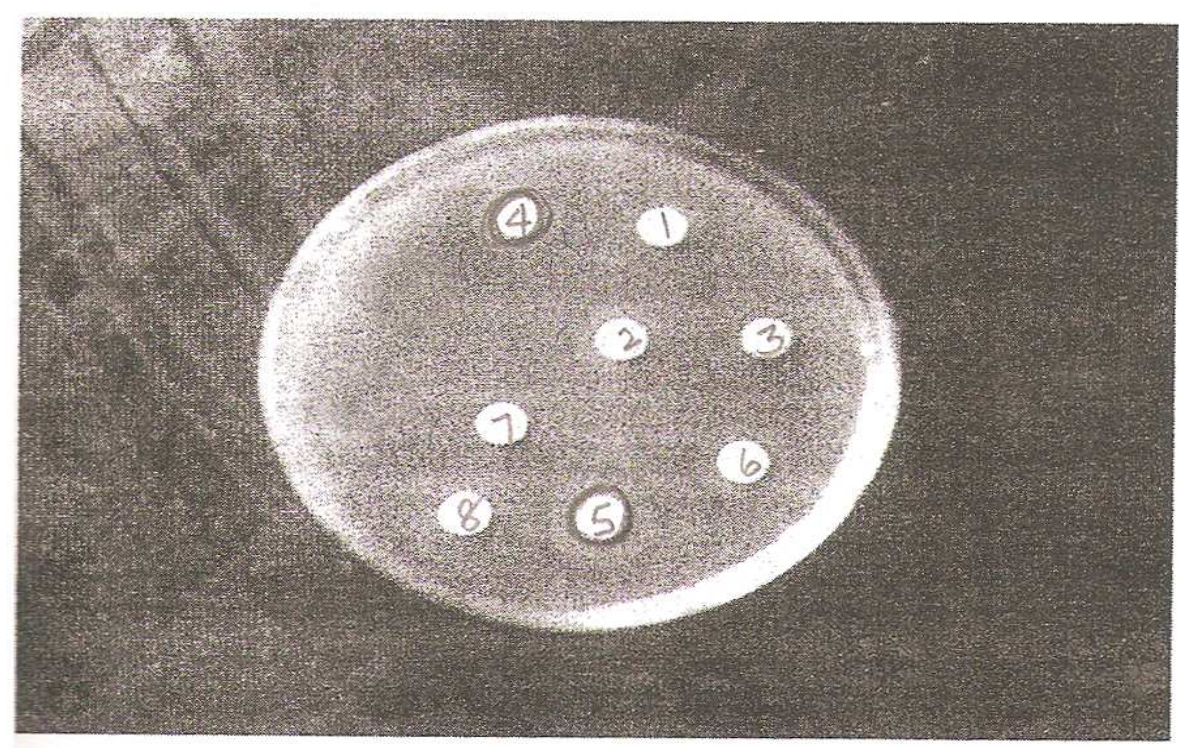

Plate 1: Pseudomonas fluorescence

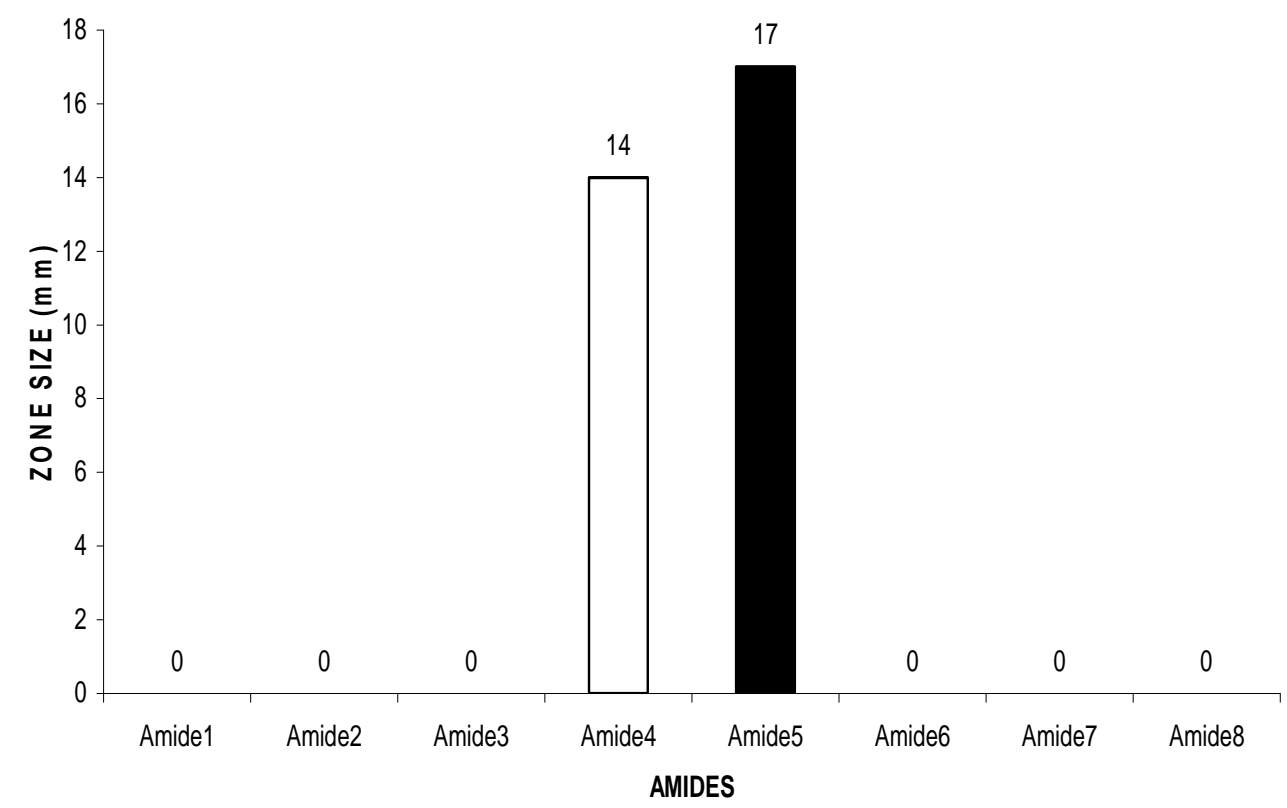

Figure 1: Antibiogram of Pseudomonas fluorescence. 


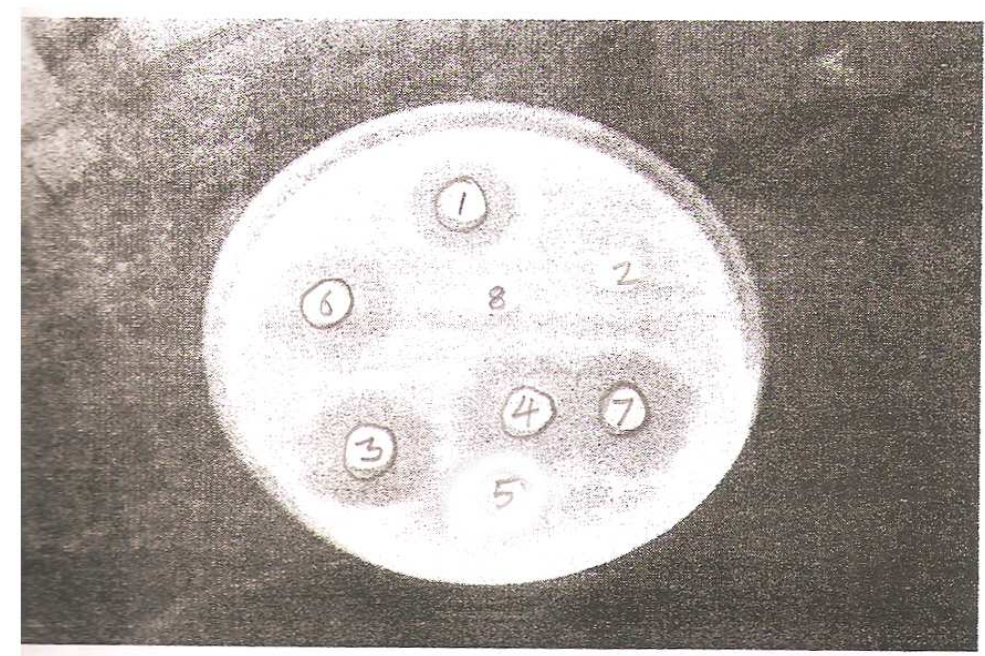

Plate 2 : Staphylococcus aureus

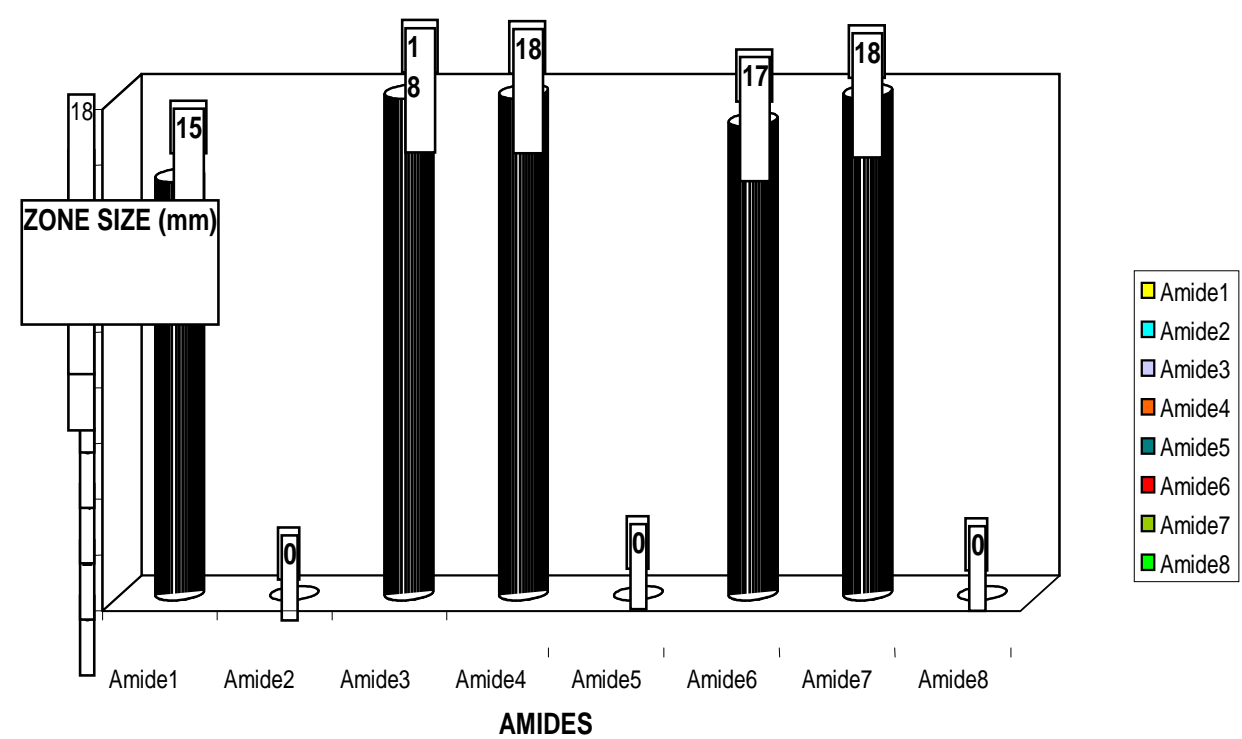

Figure 2: Antibiogram of Staphylococcus aureus.

derivatives. The peptide derivatives of aspirin having amide group acted well on the microorganisms used and showed a greater zone of inhibition ranging in size from 14 to $22 \mathrm{~mm}$. On comparing the effects of all the amides used, methionine amides of aspirin were active on $S$. aureus. Glycyl-glycyl- phenylalanyl-leucine amides of aspirin was moderately active on all the three bacterial strains used. Glycyl-Phenylalanyl-leucine amides of aspirin and glycyl-glycylmethionine amides of aspirin were not active on $P$. fluorescens. Leucine amides of aspirin was moderately active on $S$. aureus. 


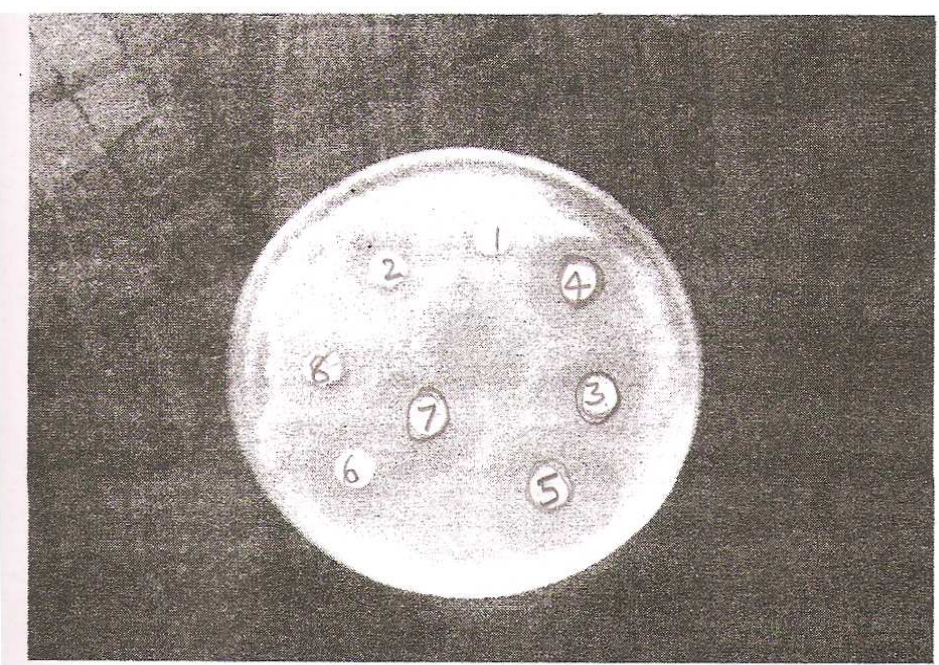

Plate 3: E. Coli

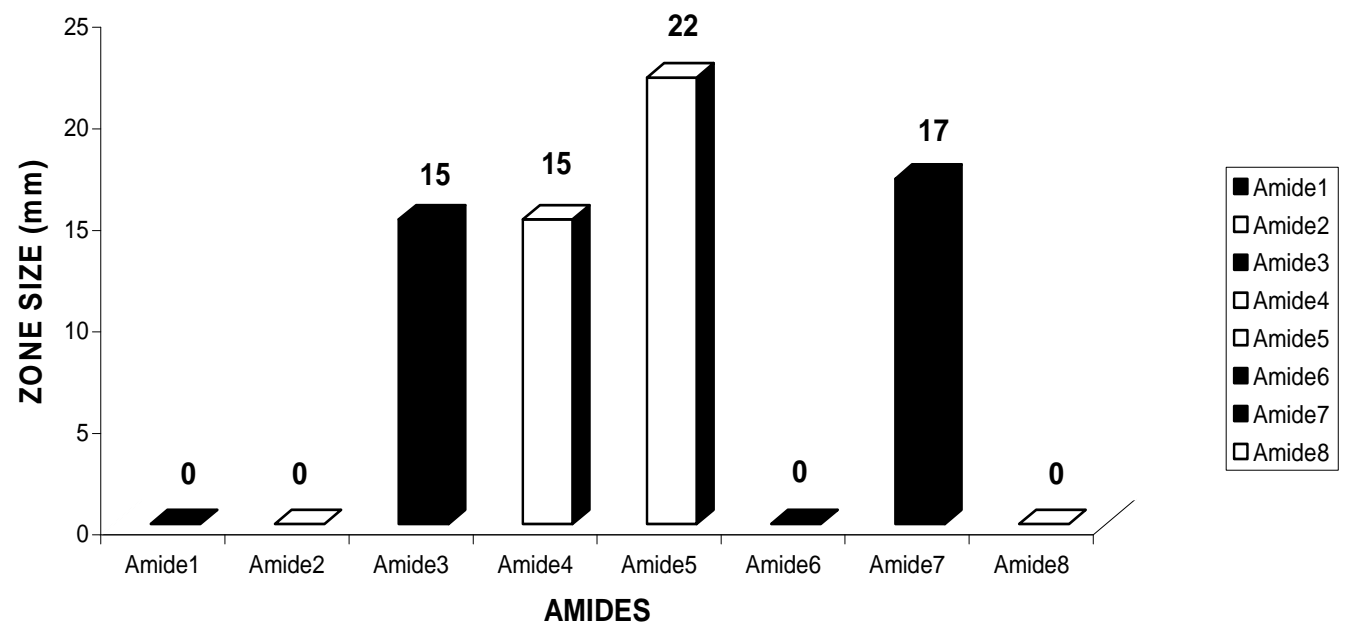

Figure 3: Antibiogram of E. Coli

Methionine amides of aspirin were highly active on E. coli. These results suggest that the addition of some amide groups to aspirin increases the antimicrobial activity. Phenylalanyl-leucine amides of aspirin and glycyl-glycyl-Phenylalanyl-methionine amide of aspirin were not active on any of the organisms used in this study.

\section{Conclusion}

From the results obtained, we can conclude that the derivative of aspirin showed a greater influence in inhibiting the test organisms used.

\section{ACKNOWLEDGEMENTS}

We thank the IISC, Bangalore for helping us in determining the NMR spectra. 


\section{REFERENCES}

Ahmad I, Beg AZ. 2001. Antimicrobial and photochemical studies on 45 Indian Medical plants against multi-drug resistant human pathogens. $J$. Ethnopharmacol., 74: 113-123.

Akinyemi KO, Oladepo O, Okawara CE, Ibe CC, Fasure KA. 2005. Screening of crude extracts of six medical plants used in South-West Nigerian unorthodox medicine for anti methcillin resistant Staphylococcus aureus activity. BMC Comp Alter Med., 5: 6-12.

Al-Bakri ag, Othman G, Bustanji Y. 2009. The assessment of the antibacterial and antifungal activities of aspirin, EDTA and aspirin-EDTA combination and their effectiveness as antibiofilm agents. Journal of applied microbiology, 107(1): 280-286.

Andrew, Wilson, Child HO. 1968. Applied Pharmacology. The English Language Book Society and $\mathrm{J}$ and A. Churchill Ltd: London; 355-357.

Anonymous. 2000. Centers for disease control and prevention. Preventing emerging infectious diseases; a strategy for the $21^{\text {st }}$ century; 1-3.

Bundi A, Grathwohl C. 1975. Proton NMR Spectra of aminoacid residues. Journal of Magnetic Resonance, 18: 191-198.

Beluzzi JD, Grant N, Garsky V, Sarantakis D, wise CD, Stein L. 1975. Tetrapeptide having analgesic activity. Nature, 260: 625-626.

Bertin A. 1992. Plasmid content and localization of STa - I (STaP) gene in enterotoxigenic E. Coli with a nonradioactive polynucleotide gene probe. $J$. Med. Microbiol., 37: 141-147.

Birscher HH, Hill RC, Romer D, Cardinaux F, Closse A, Houser D, Pless. 1976. Measurement of protein sequencestructure correlations. J, Nature, 261: 423.

Black RE. 1986. Pathogens that cause travelers diarrhoea in latin. America and Africa Rev Infect. Dis., 8: 131-135.

Blanco J, Blanco M, Garabal JI, Gonzalez EA. 1991. Enterotoxins. Colonization factors and serotypes of enterotoxigenic Escherichia coli from human and animals. Microbiologica, 7: 57-73.
Carpino LA. 1957. A facile procedure for tertbutoxycarbonylation of amines promoted by Yttria-Zirconia based strong Lewis acid catalyst. J. Am. Chem. Soc., 79: 98101.

Cragg GM, Newman DJ, Snader KM. 1997. Natural products in drug discovery and development. J. Nat. prod., 60: 52-60.

Cruckshank R, Duguid JP, Narimon BP, Swain RHA. 1975. Medical Microbiology (Vol 2, $12^{\text {th }}$ edn). Churchill Livingstone: Edinburgh, London and New York.

David A, Williams, William O, Foye. 1981. Principles of Medicinal Chemistry. Lea and Febiger; 70-75.

Gales AC, Jones RN, Turnidge J, Rennic R, Ramphal R. 2001. Characterization of Pseudomonas isolates, occurrence rates, antimicrobial susceptibility patterns and molecular typing in the global SENTRY. Antimicrobial Surveillance Programme. Clin. Infect. Dis., 32: 146- S155.

Gowan MM. 1999. Plant products as antimicrobial agents. Clin. Microbiol. Rev., 12: 564-582.

Gyles CL. 1986. Escherichia coli. In Pathogenesis of Bacterial Infections in Animals, Gyles CA, Thoen Co (eds). The Lowa State Univ. Press; 114-131.

Gyles CL. 1992. Escherichia coli cytotoxins and enterotozins. Can J. Microbiol., 38: 734-746.

Kenner GW, Galpin IJ, Ramage. 1979. Synthetic studies directed towards the synthesis of a lysozyme analog. In Peptides, Structure and Biological Function, Gross E, Meienhofer J (eds). Pierce Chemical Co.: Rockford, Illinois; 431-438.

Kundu B, Mattur KB. 1986. Glycine receptor antagonist pharmacophore. Indian $J$. Chem., 25B: 932.

Livermore DM. 2002. Multiple mechanisms of antimicrobial resistance in pseudomonas aeruginosa- our worst night mare ? Clin. Infect. Dis., 34: 634-640.

Pal A, Kar BC, Mishra PR. 1999. Antimicrobial activity of peptides. $J$. Micro World, 2: 43-45.

Patrick GL. 2000. Introduction to Medicinal Chemistry. Oxford Univ. Press; 85-94. 
Perez C, Pauli M, Bazerque P. 1990. An antibiotic assay by the well agar method. Acta Biol. Med Exp., 15: 113-115.

Polombo EA, Semple SJ. 2002, Antibacterial activity of Australian plant extracts against methicillin resistant Staphylococcus aureus (MRSA) and Vancomycin resistanct enterococi (VRE). J. Basic Microbiol., 42: 444-448.

Rani P, Khullar N. 2004. Antimicrobial evalution of some medicinal plants for their anti-enteric potential against multidrug resistant Salmonella typhi. Phytother Res., 18: 670-673.

Recio MC. 1978-1988. A review of some antimicrobial compounds isolated from medicinal plants reported in the literature 1989. Phytother Res., 3: 117-125.

Samy RP, lgnacimuthu S. 2000. Antibacterial activity of some folklore medicinal plants used by tribals in western Ghats of India. J. Ethnopharmacol., 69: 63-71.

Seigmund E, Cadmus R, Lu G. 1957. Preliminary experiments on the chemistry and pharmacology of cannabis. Proc. Soc. Exp. Biol. Med., 9: 729-731.

Snyder SH. 1980. Brain peptides as neurotransmitters. Science, 209: 976-983.

Threlfall EJ, Frost JA, Ward LR. 1996. Increasing spectrum of resistance in multiresistant Salmonella typhimurium. Lancet, 343: 1052-1054.

Wang WH, Wong WM, Dailidiene D, Berg DE, Gu Q, Lai KC, Lam SK, Wong BCY. 2003. Aspirin inhibits the growth of Helicobacter pylori and enhances its susceptibility to antimicrobial agents. Gut, 52: 490-495. 